UDC 577

\title{
Experimental and human population studies of DNA lesions in healthy individuals
}

\author{
N. Sjakste ${ }^{1,2}$ \\ ${ }^{1}$ Institute of Biology University of Latvia \\ 3, Miera Str., Salaspils, Latvia, LV-2169 \\ 2 Faculty of Medicine, University of Latvia \\ 1a, Sharlotes Str., Riga, Latvia, LV-1001 \\ Nikolajs.Sjakste@lu.lv
}

\begin{abstract}
DNA damage is a valuable biomarker in human molecular epidemiology being associated with many diseases. However, the level of DNA damage is influenced also by intrinsic features of healthy persons: heredity, sex, age and body type. The objective of this review was to summarize data on DNA breakage level in healthy humans depending on their characteristics and to compare these data with experimental studies and observations on animals dealing with the same factors. Several strains of laboratory animals manifest an increased level of DNA breaks. In humans some gene polymorphisms are associated with [an] increased level of DNA damage, however it is believed that environmental factors are more important. In animals a higher level of DNA breakage is usually detected in males. In humans data on the role of gender are contradictory and depend on race. Experimental models provide evidence of increased levels of single- and double-strand breaks in obese animals. Human studies are not so convincing, an increase of double-strand breaks appears to be a more reproducible feature of DNA of overweight persons. Data on single-strand DNA breaks in aged persons are contradictory, but double strand breaks evidently increase with age.
\end{abstract}

Ke y w o r d s: DNA breaks, aging, gender, obesity

\section{Introduction}

DNA damage by irradiation, chemicals and endogenous free radicals and further ineffective repair of these lesions are common cases of premature aging, cancer $[1,2]$, diabetes mellitus [3], neuropathies [4] and other diseases [5]. Treatment strategies of cancer and diabetes mellitus can be aimed at the DNA damage prevention and DNA repair enhancement $[6,7]$. On the other hand DNA breaks and other lesions are involved in physiological processes like cell differentiation $[8,9]$. Simplicity and precision of the "comet assay" or single cell electrophoresis have expanded substantially the circle of studied cases. DNA breaks are evaluated in

(C) 2017 N. Sjakste; Published by the Institute of Molecular Biology and Genetics, NAS of Ukraine on behalf of Biopolymers and Cell. This is an Open Access article distributed under the terms of the Creative Commons Attribution License (http://creativecommons.org/licenses/by/4.0/), which permits unrestricted reuse, distribution, and reproduction in any medium, provided the original work is properly cited 
healthy people unexposed to DNA-damaging factors depending on their gender, age, place of residence, bad or good habits, etc. Here we will try to summarize the data of some of such trials, focusing on intrinsic features of healthy persons: heredity, sex, age and body type comparing them with the data of experimental studies aimed at similar questions.

\section{Genome}

Existence of mice strains containing higher levels of DNA breaks is a well-established fact. A good example of such strains is the mice strain $101 / \mathrm{H}$ characterized by high incidence of tumours, short life span, decreased DNA repair efficiency and deafness. The molecular weight of single-strand DNA fragments from the $101 / \mathrm{H}$ mice foetal fibroblasts was found to be lower than that in CBA mice [10]. Unfortunately the gene responsible for above traits of $101 / \mathrm{H}$ strain is not revealed yet. Similarly, non-irradiated lymphoblasts of radiosensitive strain (LY-S cells) showed higher average DNA-mobility and heterogeneity in DNA-comet length as compared to the cells of radioresistant strain (LY-R). This difference is suggested to be compatible with a relatively higher background DNA-breakage in LY-S cells due to deficiency in repair of double-strand breaks in these cells [11]. Nowadays several mice strains with the characterized mutations and high level of spontaneous DNA breaks are characterized. For example, the senescence-accelerated mouse prone 8 (SAMP8) develops the accelerated senescence phenotype largely mediated by oxidative stress, due to the mutation in the $O g g 1$ gene, greatly reducing an ability of the enzyme to excise 8-hydroxy,2'-deoxyguanosine (8OHdG) adducts. Males of this strain have a high level of DNA damage in caudal epididymal spermatozoa as measured by the alkaline Comet assay [12]. DNA strand breaks are increased in Fanconi anaemia mouse model strain Fancd2(-/-), but not in Fancg(-/-) mice [13]. A persistent level of the intrinsic DNA damage in fibroblasts derived from the MRL mouse was revealed by both neutral and alkaline comet assay. These mice are characterized by an increased capacity for regeneration and down-regulation of $\mathrm{p} 21$ protein of $\mathrm{p} 53 / \mathrm{p} 21$ axis [14]. When the mice of three different strains were deprived of sleep, statistically significant differences in DNA damage were found in blood cells of the Swiss mice strain when compared to negative controls [15].

The data of studies in human population indicate some dependence of the DNA breakage level on genetical background. For example, the DNA breakage level in white blood cells is lower in black Americans compared to their white compatriots [16]. [The] Dependence of spontaneous level of DNA breaks in Czech population was reported for [the] XPC Ala499Val $(\mathrm{C} \rightarrow \mathrm{T})$ single nucleotide polymorphism [17], however these data were not reproduced in other trial performed in the same population, it turned out that Asp1104His in the $X P G$ gene is more important, carriers of 1104 His have a higher level of DNA breaks [18]. Despite the above data, a comparison of DNA repair capacity in twins indicates greater importance of environmental factors compared to hereditary factors [19].

\section{Gender}

Data of some experiments indicate the dependence of the level of DNA lesions on gender. 
For example, stress induces DNA breaks in hippocampus of rat males, but not females [20], the same dependence was observed in rat cubs separated from their mothers [21]. In dab (Limanda limanda) males, fishes living in natural conditions, DNA was also stronger damaged compared to females [22]. Males of wood mice (Apodemus sylvaticus) are much more susceptible to pollution compared to females, however no difference in DNA breakage was observed in animals living in nonpolluted areas [23].

The population study performed in Sweden indicated a higher level of single-strand breaks in men, compared to women [24]. Two studies performed in Czech Republic gave opposite results $[17,18]$. In black Americans, women had a higher level of DNA breaks, in white Americans the level of DNA breakage was the same in men and women [25]. Great contradictions between the studies do not allow making any conclusion about humans.

\section{Body mass and obesity}

The results of several studies in animals indicate an increase of DNA breaks in obese animals. This fact was confirmed on Zucker rats, the caloric restriction decreased the level of both single-strand [26] and double-strand breaks [27]. The difference was well-pronounced in sperm cells of Zucker rats [28] and two murine models of obesity [29] and parrots kept in captivity [30]. In fat mice, the pattern of promoter methylation and spectrum of microRNAs resemble these parameters in irradiated mice [31]. However, the level of oxidative DNA damage in Zucker rats was the same in several tissues of lean and obese animals, the former had even higher level of oxidised bases in hepatocytes
[32]. Some facts indicate that obesity could be consequence, but not the cause of DNA damage, knockout of the oxoguanineglycosylase 1 gene, encoding an enzyme removing the oxidised base, caused obesity in mice [33].

The data of population studies are much more contradictory. More DNA breaks were detected in overweight young Swedish women compared to lean girls, however this difference was not observed in men [24] and in male Chinese cooks [33]. In adipocytes obtained during surgery on lean and obese persons the level of DNA breaks was the same [35]. Dependence of the level of DNA breaks on the body weight was not observed in Austrians, but the level of 8-oxoguanidine was even higher in lean persons [36]. A lower 8-oxoguanidine level was detected in blood plasma of obese Turks [37] and in urine of Croatians with recently diagnosed metabolic syndrome [38]. However, some studies indicate increased levels of the oxidised base and DNA breaks in obese and metabolic syndrome patients [37, 39, 40]. Loss of weight does not increase the DNA repair capacity, this was shown on a group of elderly Canadian women, who decreased their weight by $10 \%$ [41]. The changes in DNA repair capacity were very modest also in a group of Spanish men, who put down their weight [42]. Studies on the DNA double strand breaks give more significant results, compared to studies of other DNA lesions. In white blood cells of obese adolescents the level of the DNA double-strand breaks was 6 times higher, compared to lean children [43]. Some studies indicate increased level of the DNA double-strand breaks also in spermatocytes of overweight men [44], however this result is not always reproduced [45]. 


\section{Age}

Numerous experimental studies indicate an increase of the level of DNA damage with age. The normal variations in basal DNA damage were detected by Comet assay in leukocytes from 45 female and male mice from different age groups (newborns, 3.5, 12, and 104 weeks); significantly increased values in 104 week old mice, as compared to other ages were revealed [46]. DNA damage in white blood cells of Swiss mice, measured as a tail moment in the single-cell gel electrophoresis in peripheral blood of different age groups of mice $(1,6,12$ and 18 months) showed a gradual increase with age more pronounced in females [47]. A significant DNA damage was revealed in the cardiomyocytes of rapidly aging SAMP8 mice when compared with SAMR1 mice with normal life span [48]. The level of DNA damage in brain cells from SAMR1 was unchanged from 4 to 15 months of age. In the case of SAMP1 brain cells, the DNA breaks increased in an age-related manner from 8 to 15 months of age. In the cases of liver and kidney, no changes were observed in both strains from 4 to 15 months of age. [49]. DNA damage in bone marrow cells from young and aged apoE/- mice compared with age-matched wild-type C57BL/6 (C57) mice, that was measured using the comet assay was higher in young apoE-/mice than in age-matched $\mathrm{C} 57$ mice, and increased in aged C57 and apoE-/- mice [50]. DNA breaks are increased also in the hematopoietic stem cells derived from old mice [51]. When the comet assay was used to investigate the level of oxidatively damaged DNA in several organs of ApoE(-/-) mice as strand breaks, endonuclease III- and formamidopyrimidine DNA glycosylase-sensitive sites, the level of
DNA damage mainly increased with age in the liver, whereas no increase was observed in the aorta or lung of the mice [52]. The 8-oxodGuo levels were also significantly higher in older mouse liver DNA. The primary lung fibroblasts cultured from older mice had significantly greater levels of strand breaks than cells derived from young mice [53]. The level of oxidized purines and pyrimidines was found to be higher in aortic cells of 26 months old mice compared to six months old mice [54].

The data on wild rodents are not so convincing. The effects of environmental pollution on genetic damage in wood mice (Apodemus sylvaticus) were investigated by means of the comet assay at several sites in Belgium differing in the level of pollution, with special attention to the role of age as a potential confounding variable. A significant increase in genetic damage with age was observed at the most polluted sites, but not at the clean sites [23].

Some authors report an increase of DNA damage in lymphocytes in old rats [55], others observe an opposite trend [56]. In whole blood nucleated cells the level of DNA breaks increased in 19 months old rats compared to 2 months old rats [57], in 9 months old rats the difference was not yet detectable [58]. The breaks could be observed in optic nerve of old rats [59], the DNA single- and double-strand breaks as well as the oxidative damage increased also in astrocytes and neurons [60]. Similar increase was observed in livers and kidneys of old rats [61], but in these organs alkali-labile sites were the only age-related DNA lesions, no increase in double-strand breaks was observed [62] (Hashimoto et al., 2007). Thus, the experimental studies indicate an increase of DNA lesions with aging, how- 
ever some contradictory data have been published. To overcome these contradictions, a combined parameter, "differential of DNA lesions" has been proposed [63]. The study was conducted on mice leukocytes, the authors did not detect any increase in the level of single-strand breaks, however the level of oxidised purines increased in animals of both sexes, oxidised pyrimidines - in males only, double-strand breaks - in females. Calculation of the "differential of DNA lesions", taking into account the level of oxidized purines, double strand breaks and DNA methylation levels, indicated an obvious increase of DNA lesions with age. Nowadays the double-strand breaks are considered by many scientists as the most important in aging [64]; it is supposed that these DNA lesions form a link between an increase of entropy with age and process of senescence [65]. It was hypothesized that the strongest argument in favour of determinative role of double-strand breaks in senescence could be the increased life span of animals with strong expression of the proteins involved in repair of double-strand breaks. The promising results were obtained on mice with [the] hyperexpressed SIRT 6 transcription factor [66]. Inefficient repair of double-strand breaks and decreased expression of the enzymes involved in non-homologous end joining were observed also in the fibroblasts derived from elderly persons. The transfections of plasmids with XRCC4 and DNA ligase 4 genes, causing hyperexpression of these proteins, triggered rejuvenation of these cells [67]. Comparison of the expression of enzymes involved in repair of double-strand breaks in short living (mouse) and long-living (humans and the nude mole rat) species indi- cates a higher efficiency of above repair process in long-living species [68]. A controlled induction of double-strand breaks by transfection of adenovirus with Sac I restrictase gene triggered the signs of senescence in the liver of mice [69]. The DNA breaks caused by photosensitizing compounds [70] and heat shock lead to comparable effects [71].

Compared to the experimental data, the results of human population studies are far from being convincing. After reviewing numerous publications on the topic it was concluded that no definite assertion is possible, some publications indicate an increase, whereas others - decrease or stable level of DNA lesions with aging [72]. Some authors admit the accumulation of double-strand breaks, but not oxidative lesions or single-strand breaks [73]. Using a novel modification of immunofluorescence method, an increase of $\gamma \mathrm{H} 2 \mathrm{AX}$ foci (marker of doublestrand breaks) in lymphocytes with age was demonstrated, but the conclusion was true only for persons of Hispanic origin [74]. In a scrupulous study performed by Løhr and co-authors [75], no increase of single strand breaks was revealed, the oxidised bases increased only in elderly women. The latter parameter correlated with the cholesterol level and other metabolic deviations. Thus, the classical question: "Which came first, the chicken or the egg?" emerges. It is well known that the cholesterol level increases with age and is involved in the development of the senile phenotype.

\section{Conclusions}

The experimental studies provide an apparent evidence of dependence of the level of DNA breaks on the intrinsic features of organisms like genotype, gender, age and body type. The 
results of population studies confirm the same trends, but are not so convincing. To our opinion, an application of other methods, pulse-field gel electrophoresis for example, in combination with "monopolising" comet assay could enhance the credibility and reproducibility of the results. Increasing number of studies performed not only on white blood cells, but also on buccal epithelium or other accessible human tissues could lead to clearer conclusions.

\section{Funding}

The work was supported in part by the European Regional Development foundation activity $1.1 .1 .1 / 16 / \mathrm{A}$ project "Identification of proteasome related genetic, epigenetic and clinical markers for multiple sclerosis". The author thanks colleagues from the $C A C O S T$ Action CA15132 "The comet assay as a human biomonitoring tool (hCOMET)" for stimulating discussions.

\section{REFERENCES:}

1. Magnander K, Elmroth K. Biological consequences of formation and repair of complex DNA damage. Cancer Lett. 2012;327(1-2):90-6.

2. Stone MP, Huang H, Brown KL, Shanmugam G. Chemistry and structural biology of DNA damage and biological consequences. Chem Biodivers. 2011;8(9):1571-615.

3. Selvaraju V, Joshi M, Suresh S, Sanchez JA, Maulik N, Maulik G. Diabetes, oxidative stress, molecular mechanism, and cardiovascular disease--an overview. Toxicol Mech Methods. 2012;22(5):330-5.

4. Supriya Simon A, Dinesh Roy D, Jayapal V, Vijayakumar T. Somatic DNA damages in cardiovascular autonomic neuropathy. Indian $J$ Clin Biochem. 2011;26(1):50-6.

5. Milic M, Frustaci A, Del Bufalo A, Sánchez-Alarcón J, Valencia-Quintana R, Russo P, Bonassi S. DNA damage in non-communicable diseases:
A clinical and epidemiological perspective. Mutat Res. 2015;776:118-27.

6. Algire C, Moiseeva O, Deschênes-Simard X, Amrein L, Petruccelli L, Birman E, Viollet B, Ferbeyre $G$, Pollak $M N$. Metformin reduces endogenous reactive oxygen species and associated DNA damage. Cancer Prev Res (Phila). 2012;5(4):536-43.

7. Aziz K, Nowsheen S, Pantelias G, Iliakis G, Gorgoulis $V G$, Georgakilas $A G$. Targeting DNA damage and repair: embracing the pharmacological era for successful cancer therapy. Pharmacol Ther. 2012;133(3):334-50.

8. Sjakste N, Sjakste T. Possible involvement of DNA strand breaks in regulation of cell differentiation. Eur J Histochem. 2007;51(2):81-94.

9. Sjakste NI, Sjakste TG. Possible involvement of DNA breaks in epigenetic regulation of cell differentiation. Rus J Genet. 2007; 43(5):467-84.

10. Sjakste TG, Lilp IG, Sjakste TG. Chromosomal aberrations and molecular weight of single - stranded DNA fragments in embryonic fibroblasts of 101. $\mathrm{H}$ and CBA mice. Bull Exp Biol Med. 1981; 92(3):1231-3.

11. Tronov VA, Grin'ko EV, Afanas'ev GG, Filippovich $I V$. [Study of DNA damage and heterogeneity of cells by a gel microelectrophoresis method]. Biofizika. 1994;39(5):810-9.

12. Smith TB, De Iuliis GN, Lord T, Aitken RJ. The senescence-accelerated mouse prone 8 as a model for oxidative stress and impaired DNA repair in the male germ line. Reproduction. 2013;146(3):253-62.

13. Reliene R, Yamamoto ML, Rao PN, Schiestl RH. Genomic instability in mice is greater in Fanconi anemia caused by deficiency of Fancd 2 than Fancg. Cancer Res. 2010;70(23):9703-10.

14. Bedelbaeva K, Snyder A, Gourevitch D, Clark L, Zhang XM, Leferovich J, Cheverud JM, Lieberman P, Heber-Katz E. Lack of p21 expression links cell cycle control and appendage regeneration in mice. Proc Natl Acad Sci U S A. 2010;107(13):5845-50.

15. Kahan V, Ribeiro DA, Andersen ML, Alvarenga TA, Tufik $S$. Sleep loss induces differential response related to genotoxicity in multiple organs of three different mice strains. Basic Clin Pharmacol Toxicol. 2010;107(1):598-602. 
16. Watters JL, Satia JA, Kupper LL, Swenberg JA, Schroeder JC, Switzer BR. Associations of antioxidant nutrients and oxidative DNA damage in healthy African-American and White adults. Cancer Epidemiol Biomarkers Prev. 2007;16(7):1428-36.

17. Slyskova J, Naccarati A, Polakova V, Pardini B, Vodickova L, Stetina R, Schmuczerova J, Smerhovsky Z, Lipska L, Vodicka P. DNA damage and nucleotide excision repair capacity in healthy individuals. Environ Mol Mutagen. 2011;52(7):511-7.

18. Slyskova J, Lorenzo Y, Karlsen A, Carlsen MH, Novosadova V, Blomhoff R, Vodicka P, Collins AR. Both genetic and dietary factors underlie individual differences in DNA damage levels and DNA repair capacity. DNA Repair (Amst). 2014;16:66-73.

19. Garm C, Moreno-Villanueva M, Bürkle A, Larsen LA, Bohr VA, Christensen K, Stevnsner T. Genetic and environmental influence on DNA strand break repair: a twin study. Environ Mol Mutagen. 2013;54(6):414-20.

20. Noschang CG, Pettenuzzo LF, von Pozzer Toigo E, Andreazza AC, Krolow R, Fachin A, Avila MC, Arcego D, Crema LM, Diehl LA, Gonçalvez CA, Vendite $D$, Dalmaz $C$. Sex-specific differences on caffeine consumption and chronic stress-induced anxiety-like behavior and DNA breaks in the hippocampus. Pharmacol Biochem Behav. 2009;94(1):63-9.

21. Noschang CG, Krolow R, Fontella FU, Arcego DM, Diehl LA, Weis SN, Arteni NS, Dalmaz C. Neonatal handling impairs spatial memory and leads to altered nitric oxide production and DNA breaks in a sex specific manner. Neurochem Res. 2010;35(7):1083-91.

22. Akcha F, Leday G, Pfohl-Leszkowicz A. Measurement of DNA adducts and strand breaks in dab (Limanda limanda) collected in the field: effects of biotic (age, sex) and abiotic (sampling site and period) factors on the extent of DNA damage. $M u$ tat Res. 2004;552(1-2):197-207.

23. Scheirs J, De Coen A, Covaci A, Beernaert J, Kayawe VM, Caturla M, De Wolf H, Baert P, Van Oostveldt $P$, Verhagen $R$, Blust $R$, De Coen $W$. Genotoxicity in wood mice (Apodemus sylvaticus) along a pollution gradient: exposure-, age-, and gender-related effects. Environ Toxicol Chem. 2006;25(8): 2154-62.
24. Hofer T, Karlsson HL, Möller L. DNA oxidative damage and strand breaks in young healthy individuals: a gender difference and the role of life style factors. Free Radic Res. 2006;40(7):707-14.

25. Trzeciak AR, Barnes J, Ejiogu N, Foster K, Brant LJ, Zonderman $A B$, Evans $M K$. Age, sex, and race influence single-strand break repair capacity in a human population. Free Radic Biol Med. 2008;45(12):1631-41.

26. Molz P, Ellwanger JH, Zenkner FF, Campos D, Prá D, Putzke MT, Franke SI. Recognition memory and DNA damage in undernourished young rats. $A n$ Acad Bras Cienc. 2016;88(3 Suppl):1863-73.

27. Bankoglu EE, Seyfried F, Rotzinger L, Nordbeck A, Corteville C, Jurowich C, Germer CT, Otto C, Stopper $H$. Impact of weight loss induced by gastric bypass or caloric restriction on oxidative stress and genomic damage in obese Zucker rats. Free Radic Biol Med. 2016;94:208-17.

28. Vendramini V, Cedenho AP, Miraglia SM, Spaine $D M$. Reproductive function of the male obese Zucker rats: alteration in sperm production and sperm DNA damage. Reprod Sci. 2014;21(2):221-9.

29. Duale N, Steffensen IL, Andersen J, Brevik A, Brunborg $G$, Lindeman $B$. Impaired sperm chromatin integrity in obese mice. Andrology. 2014;2(2):234-43.

30. Larcombe SD, Tregaskes CA, Coffey J, Stevenson AE, Alexander LG, Arnold KE. Oxidative stress, activity behaviour and body mass in captive parrots. Conserv Physiol. 2015;3(1):cov045.

31. Vares G, Wang B, Ishii-Ohba H, Nenoi M, Nakajima $T$. Diet-induced obesity modulates epigenetic responses to ionizing radiation in mice. PLoS One. 2014;9(8):e106277.

32. Løhr M, Folkmann JK, Sheykhzade M, Jensen LJ, Kermanizadeh A, Loft S, Møller P. Hepatic oxidative stress, genotoxicity and vascular dysfunction in lean or obese Zucker rats. PLoS One. 2015;10(3):e0118773.

33. Sampath H, Vartanian V, Rollins MR, Sakumi K, Nakabeppu Y, Lloyd RS. 8-Oxoguanine DNA glycosylase (OGG1) deficiency increases susceptibility to obesity and metabolic dysfunction. PLoS One. 2012;7(12):e51697.

34. Wang J, Luo X, Xu B, Wei J, Zhang Z, Zhu H. Elevated oxidative damage in kitchen workers in Chinese restaurants. J Occup Health. 2011;53(5):327-33. 
35. Jones DA, Prior SL, Barry JD, Caplin S, Baxter JN, Stephens $J W$. Changes in markers of oxidative stress and DNA damage in human visceral adipose tissue from subjects with obesity and type 2 diabetes. Diabetes Res Clin Pract. 2014;106(3):627-33.

36. Wallner M, Antl N, Rittmannsberger B, Schreidl S, Najafi K, Müllner E, Mölzer C, Ferk F, Knasmüller S, Marculescu R, Doberer D, Poulsen HE, Vitek L, Bulmer AC, Wagner KH. Anti-genotoxic potential of bilirubin in vivo: damage to DNA in hyperbilirubinemic human and animal models. Cancer Prev Res (Phila). 2013;6(10):1056-63.

37. Donmez-Altuntas H, Sahin F, Bayram F, Bitgen N, Mert M, Guclu K, Hamurcu Z, Arıbas S, Gundogan $K$, Diri $H$. Evaluation of chromosomal damage, cytostasis, cytotoxicity, oxidative DNA damage and their association with body-mass index in obese subjects. Mutat Res Genet Toxicol Environ Mutagen. 2014;771:30-6.

38. Milić M, Kišan M, Rogulj D, Radman M, Lovrenčić MV, Konjevoda P, Domijan AM. Level of primary DNA damage in the early stage of metabolic syndrome. Mutat Res. 2013;758(1-2):1-5.

39. Karaman A, Aydın H, Geçkinli B, Çetinkaya A, Karaman $S$. DNA damage is increased in lymphocytes of patients with metabolic syndrome. Mutat Res Genet Toxicol Environ Mutagen. 2015;782:30-5.

40. Karbownik-Lewinska M, Szosland J, KokoszkoBilska A, Stepniak J, Zasada K, Gesing A, Lewinski $A$. Direct contribution of obesity to oxidative damage to macromolecules. Neuro Endocrinol Lett. 2012;33(4):453-61.

41. Habermann N, Makar KW, Abbenhardt C, Xiao L, Wang CY, Utsugi HK, Alfano CM, Campbell KL, Duggan C, Foster-Schubert KE, Mason CE, Imayama I, Blackburn GL, Potter JD, McTiernan A, Ulrich $C M$. No effect of caloric restriction or exercise on radiation repair capacity. Med Sci Sports Exerc. 2015;47(5):896-904.

42. Ibero-Baraibar I, Azqueta A, Lopez de Cerain A, Martinez JA, Zulet MA. Assessment of DNA damage using comet assay in middle-aged overweight/obese subjects after following a hypocaloric diet supplemented with cocoa extract. Mutagenesis. 2015; 30(1):139-46.
43. Azzarà A, Pirillo C, Giovannini C, Federico $G$, Scarpato $R$. Different repair kinetic of DSBs induced by mitomycin $\mathrm{C}$ in peripheral lymphocytes of obese and normal weight adolescents. Mutat Res. 2016;789:9-14.

44. Dupont C, Faure C, Sermondade N, Boubaya M, Eustache F, Clément P, Briot P, Berthaut I, Levy V, Cedrin-Durnerin I, Benzacken B, Chavatte-Palmer $P$, Levy $R$. Obesity leads to higher risk of sperm DNA damage in infertile patients. Asian J Androl. 2013;15(5):622-5.

45. Eisenberg ML, Kim S, Chen Z, Sundaram R, Schisterman EF, Buck Louis GM. The relationship between male BMI and waist circumference on semen quality: data from the LIFE study. Hum Reprod. 2014;29(2):193-200.

46. Heuser VD, de Andrade VM, Peres A, Gomes de Macedo Braga LM, Bogo Chies JA. Influence of age and sex on the spontaneous DNA damage detected by micronucleus test and comet assay in mice peripheral blood cells. Cell Biol Int. 2008;32(10):1223-9.

47. Bhilwade HN, Jayakumar S, Chaubey RC. Age-dependent changes in spontaneous frequency of micronucleated erythrocytes in bone marrow and DNA damage in peripheral blood of Swiss mice. Mutat Res Genet Toxicol Environ Mutagen. 2014;770:80-4.

48. Sreedhar R, Giridharan VV, Arumugam S, Karuppagounder V, Palaniyandi SS, Krishnamurthy $P$, Quevedo J, Watanabe K, Konishi T, Thandavarayan $R A$. Role of MAPK-mediated endoplasmic reticulum stress signaling in the heart during aging in senescence-accelerated prone mice. Biofactors. 2016;42(4):368-75.

49. Hayashi M, Nishida K, Endoh D, Okui T. Production of age-related DNA strand breakage in brain cells of senescence-accelerated prone (SAMP1) mouse. Exp Anim. 2003;52(4):353-7.

50. Tonini CL, Campagnaro BP, Louro LP, Pereira TM, Vasquez EC, Meyrelles SS. Effects of aging and hypercholesterolemia on oxidative stress and DNA damage in bone marrow mononuclear cells in apolipoprotein E-deficient Mice. Int J Mol Sci. 2013; 14(2):3325-42.

51. Beerman I, Seita J, Inlay MA, Weissman IL, Rossi DJ. Quiescent hematopoietic stem cells accumulate DNA 
damage during aging that is repaired upon entry into cell cycle. Cell Stem Cell. 2014;15(1):37-50.

52. Folkmann JK, Loft S, Møller P. Oxidatively damaged DNA in aging dyslipidemic ApoE-/- and wildtype mice. Mutagenesis. 2007;22(2):105-10.

53. López-Diazguerrero NE, Luna-López A, GutiérrezRuiz MC, Zentella A, Königsberg M. Susceptibility of DNA to oxidative stressors in young and aging mice. Life Sci. 2005;77(22):2840-54.

54. Guo ZM, Yang H, Hamilton ML, VanRemmen H, Richardson A. Effects of age and food restriction on oxidative DNA damage and antioxidant enzyme activities in the mouse aorta. Mech Ageing Dev. 2001;122(15):1771-86.

55. Sivonová M, Tatarková Z, Duracková Z, Dobrota D, Lehotský J, Matáková T, Kaplán P. Relationship between antioxidant potential and oxidative damage to lipids, proteins and DNA in aged rats. Physiol Res. 2007;56(6):757-64.

56. Gedik CM, Grant G, Morrice PC, Wood SG, Collins $A R$. Effects of age and dietary restriction on oxidative DNA damage, antioxidant protection and DNA repair in rats. Eur J Nutr. 2005;44(5):263-72.

57. Sahhugi Z, Hasenan SM, Jubri Z. Protective effects of gelam honey against oxidative damage in young and aged rats. Oxid Med Cell Longev. 2014;2014:673628.

58. Jubri Z, Rahim NB, Aan GJ. Manuka honey protects middle-aged rats from oxidative damage. Clinics (Sao Paulo). 2013;68(11):1446-54.

59. El-Sayyad HI, Khalifa SA, El-Sayyad FI, Al-Gebaly AS, El-Mansy AA, Mohammed EA. Aging-related changes of optic nerve of Wistar albino rats. Age (Dordr). 2014;36(2):519-32.

60. Swain U, Subba Rao K. Study of DNA damage via the comet assay and base excision repair activities in rat brain neurons and astrocytes during aging. Mech Ageing Dev. 2011;132(8-9):374-81.

61. Hashimoto K, Takasaki W, Yamoto T, Manabe S, Sato I, Tsuda S. Effect of glutathione (GSH) depletion on DNA damage and blood chemistry in aged and young rats. $J$ Toxicol Sci. 2008;33(4):421-9.

62. Hashimoto K, Takasaki W, Sato I, Tsuda S. DNA damage measured by comet assay and $8-\mathrm{OH}-\mathrm{dG}$ formation related to blood chemical analyses in aged rats. J Toxicol Sci. 2007;32(3):249-59.
63. Velegzhaninov I, Mezenceva V, Shostal O, Baranova A, Moskalev A. Age dynamics of DNA damage and $\mathrm{CpG}$ methylation in the peripheral blood leukocytes of mice. Mutat Res. 2015;775:38-42.

64. White RR, Vijg J. Do DNA double-strand breaks drive aging? Mol Cell. 2016;63(5):729-38.

65. Lenart P, Bienertová-Vaškủ J. Double strand breaks may be a missing link between entropy and aging. Mech Ageing Dev. 2016;157:1-6.

66. Gorbunova V, Seluanov A. DNA double strand break repair, aging and the chromatin connection. Mutat Res. 2016;788:2-6.

67. Li Z, Zhang W, Chen Y, Guo W, Zhang J, Tang H, $X u$ Z, Zhang H, Tao Y, Wang F, Jiang Y, Sun FL, Mao Z. Impaired DNA double-strand break repair contributes to the age-associated rise of genomic instability in humans. Cell Death Differ. 2016;23(11):1765-77.

68. MacRae SL, Croken MM, Calder RB, Aliper A, Milholland B, White RR, Zhavoronkov A, Gladyshev VN, Seluanov A, Gorbunova V, Zhang ZD, Vijg J. DNA repair in species with extreme lifespan differences. Aging (Albany NY). 2015;7(12):1171-84.

69. White RR, Milholland B, de Bruin A, Curran S, Laberge RM, van Steeg H, Campisi J, Maslov AY, Vijg $J$. Controlled induction of DNA double-strand breaks in the mouse liver induces features of tissue ageing. Nat Commun. 2015;6:6790.

70. Petrova NV, Luzhin AV, Serebrovskaya EO, Ryumina AP, Velichko AK, Razin SV, Kantidze OL. Inducing cellular senescence in vitro by using genetically encoded photosensitizers. Aging (Albany NY). 2016;8(10):2449-2462.

71. Velichko AK, Petrova NV, Razin SV, Kantidze OL. Mechanism of heat stress-induced cellular senescence elucidates the exclusive vulnerability of early S-phase cells to mild genotoxic stress. Nucleic Acids Res. 2015;43(13):6309-20.

72. Collins AR, Azqueta A. DNA repair as a biomarker in human biomonitoring studies; further applications of the comet assay. Mutat Res. 2012;736(1-2):122-9.

73. Lenart P, Krejci L. DNA, the central molecule of aging. Mutat Res. 2016;786:1-7.

74. Sharma PM, Ponnaiya B, Taveras M, Shuryak I, Turner H, Brenner DJ. High throughput measure- 
ment of $\gamma \mathrm{H} 2 \mathrm{AX}$ DSB repair kinetics in a healthy human population. PLoS One. 2015;10(3): 0121083. 75. Løhr M, Jensen A, Eriksen L, Grønboek M, Loft S, Møller P. Age and metabolic risk factors associated with oxidatively damaged DNA in human peripheral blood mononuclear cells. Oncotarget. 2015;6(5):2641-53.

\section{Експериментальні та популяційні дослідження рівня пошкоджень ДНК е здорових організмах}

\section{Н. Сьяксте}

Пошкодження ДНК є інформативним біомаркером для молекулярної епідеміології, так як вони пов'язані $з$ багатьма захворюваннями людини. У той же час рівень пошкоджень ДНК може залежати від внутрішніх властивостей притаманних здоровим людям: спадковості, статі, віку і статури. Метою даного огляду є узагальнення даних щодо розривів ДНК у здорових людей в залежності від їхніх характеристик у порівняння 3 даними експериментів і спостережень за тваринами. У лабораторних тварин кількох ліній спостерігають підвищений рівень розривів ДНК, у людини - кілька генних поліморфізмів асоційовані з підвищеним рівнем розривів, але вважається, що визначальними $є$ зовнішні фактори. У самців тварин ДНК пошкоджена сильніше, ніж у самиць, дані по людині суперечливі і залежать від раси. Експериментальні моделі показують підвищений рівень одно- і дволанцюгових розривів ДНК при ожирінні. Дані досліджень на людині менш переконливі, краще відтворюються дані щодо підвищеного рівеня дволанцюгових розривів ДНК у людей із зайвою вагою. По одноланцюгових розривах ДНК при старінні дані суперечливі, переконливо показано зростання дволанцюгових розривів ДНК з віком.

Кл юч о в і сл о в а: розриви ДНК, старіння, стать, ожиріння.

\section{Экспериментальные и популяционные исследования уровня повреждений ДНК в здоровых организмах}

\section{Н. Сьяксте}

Повреждения ДНК являются информативным биомаркером для молекулярной эпидемиологии, так как они связаны со многими заболеваниями человека. В то же время уровень повреждений ДНК может зависеть от внутренних свойств, присущих здоровым людям, от наследственности, пола, возраста и телосложения. Целью данного обзора будет обобщение данных о разрывах ДНК у здоровых людей в зависимости от их характеристик и сравнение с данными экспериментов и наблюдений на животных. У лабораторныз животных нескольких линий наблюдают повышенный уровень разрывов ДНК, у людей несколько генных полиморфизмов ассоциированы с повышенным уровнем разрывов, но считается, что определяющими являются внешние факторы. У самцов животных ДНК повреждена сильнее, чем у самок, данные по людям противоречивы и зависят от расы. Экспериментальные модели указывают на повышеннй уровень одно- и двунитевых разрывов ДНК при ожирении. Данные исследований на людях менее убедительны, лучше воспроизволдятся данные, указывающие на повышенный уровень двунитевых разрывов ДНК у людей с лишним весом. Данные по однонитевым разрывам ДНК при старении противоречивы, убедительно показано нарастание двунитевых разрывов ДНК с возрастом.

К л юч е в ы е с л ов а: разрывы ДНК, старение, пол, ожирение.

Received 10.10.2016 